\title{
Penile prolapse in Euphrates soft-shelled turtle (Rafetus euphraticus Daudin, 1802)
}

\section{Fırat yumuşak kabuklu kaplumbağasında (Rafetus euphraticus Daudin, 1802) penis prolapsusu}

\author{
Zafer Doğu1* - Faruk Aral2 ${ }^{2}$ - Erdinç Şahinöz' ${ }^{1}$ - Ertan Taşkavak ${ }^{3}$ \\ ${ }^{1}$ Department of Fisheries and Aquaculture, Bozova Vocational High School, Harran University 63850, Bozova, Şanlıurfa, Turkey \\ 2Department of Veterinary, Ulukışla Vocational School, Nigde University, Niğde, Turkey \\ ${ }^{3}$ Faculty of Fisheries, Ege University, 35100 Bornova-izmir, Turkey \\ .*Corresponding Author: zafer_dogu@yahoo.com
}

\section{How to cite this paper:}

Doğu, Z., Aral, F., Şahinöz, E., Taşkavak, E., 2015. Penile prolapse in Euphrates soft-shelled turtle (Rafetus euphraticus Daudin, 1802). Ege J Fish Aqua Sci 32(3): 169-172. doi: 10.12714/egejfas.2015.32.3.08

Özet: Erkek kaplumbağalarda phallus (penis) prolapsusu nadiren görülür. Penis çiftleşme, travma veya ölüm haricinde kloakanın ventral yüzeyinde retrakte bir şekilde uzanır. Çalışma materyalini erkek Yumuşak Kabuklu Fırat Kaplumbağası oluşturdu. Klinik olarak phallus'ta nekrotik alanlar gözlendi. Sağaltımda lokal anestezi ve analjeziyi takiben phallus'un kloaka yerleştirilmesi gerçekleştirldi. Bu olgu Yumuşak Kabuklu Fırat Kaplumbağasında bildirilen ilk penis prolopsusu olgusudur.

Anahtar kelimeler: Penis prolopsusu, Yumuşak Kabuklu Fırat Kaplumbağası, Rafetus euphraticus, tehlike altındaki türler

Abstract: Male tortoises are occasionally presented with a prolapsed phallus (penis). The penis is retracted except during mating, trauma, or death; it lies in the ventral floor of the cloaca. Male Euphrates soft-shelled turtle constituted the study material. Clinically, necrotic areas in the phallus were observed. After the local anesthesia and analgesia, phallus was inserted into the base of cloaca. This case is the first phallus prolapse case of the male Euphrates soft-shelled turtle.

Keywords: Penis prolapse, Euphrates softshell turtle, Rafetus euphraticus, threatened species

\section{INTRODUCTION}

Prolapse in reptiles can involve the cloaca, a common receiving chamber for the reproductive, urinary, and gastrointestinal tracts. Prolapses can also originate from the distal gastrointestinal tract, reproductive organ, or urinary bladder.

The underlying cause of prolapse is often related to straining or tenesmus and dyschezia caused by infection, inflammation, or trauma. Prolapse can also develop secondary to constipation or fecal impaction caused by ingestion of a foreign body such as sand, bark chips, or gravel. Prolapse can also be associated with neurologic dysfunction or general debilitation in all reptiles (Innis and Boyer, 2002; MartinezJimenez and Hernandez-Divers, 2007).

Once prolapsed, the organ can become desiccated and necrotic if it is not reduced. In cases where an animal presents with a prolapsed phallus, attempts should be made to assess the status of the organ, determine its viability, and consider whether the organ should be reduced or amputated. In cases where the tissue is still considered viable, the organ should be reduced (Nisbet et al., 2011).

The Euphrates softshell turtle (Rafetus euphraticus Daudin, 1802 ) is globally threatened and listed as Critically Endangered (CR) (IUCN, 2010). It has a global distribution centered on the river basins of Euphrates and Tigris, occupying from South East Anatolia in the west through Syria and Iraq to southwestern Iran. Adult and young animals tend to prefer shallow, slow flowing water with a high water temperature, conditions now rare on the Euphrates following completion of the Atatürk and Birecik dams (Taşkavak, 1995 and 1998).

The purpose of this report is to present our experience with the diagnosis and treatment of the necrotic phallus in the Euphrates softshell turtle that is listed as Critically Endangered in the IUCN Red List of Threatened Species (The International Union for the Conservation of Nature) and has limited 
knowledge on reproduction biology.

\section{Locality, Biologic Data and Treatment}

Male Euphrates softshell turtle (Rafetus euphraticus) was caught by fisherman's nets at 10:00 o'clock on November 15th 2009 between Aşağı Çatak and Kasım Kuyu near the Atatürk Dam Lake. Capturing area has small islands and swamp-mudclay soil. Then, the turtle was brought to Bozova Vocational High School (Fig 1).

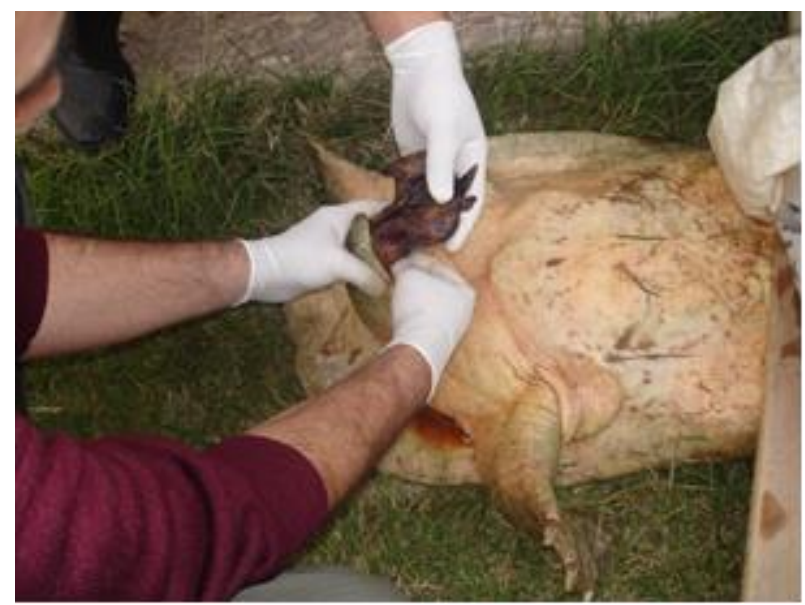

Figure 1. Examining male Euphrates soft-shelled turtle at Bozova Vocational High School

Turtle was rescued from gillnets. Male Euphrates softshell turtle with 12,400 grams body mass was found as restless and exhausted. Close examination revealed that the protruding mass from the anus was prolapsed penis. The prolapsed penis was approximately $10 \mathrm{~cm}$ in length and there was no tissue sensitivity (Fig 2).

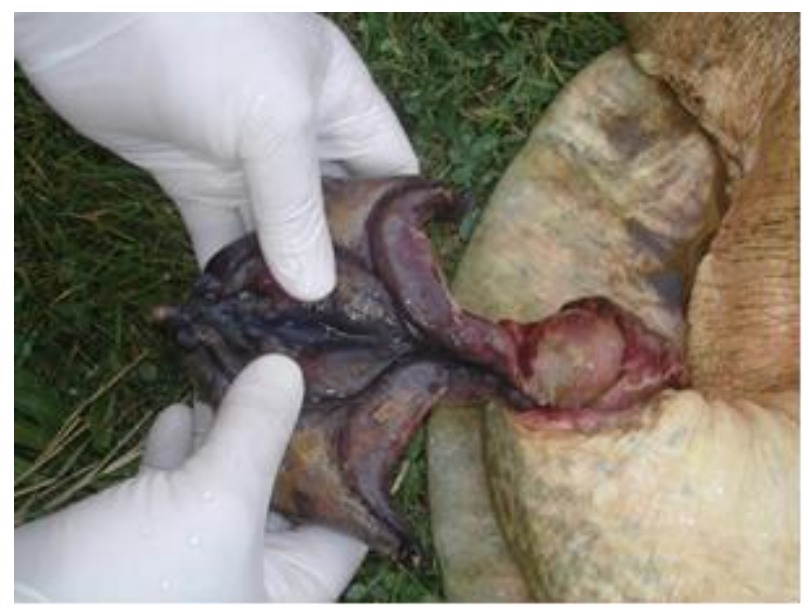

Figure 2. Close examination of pentifid (five-lobed) penis structure of Rafetus euphraticus
Necrotic areas, hemorrhages and oedema were seen on the penis (Fig 3). Various insect larvae were also observed.

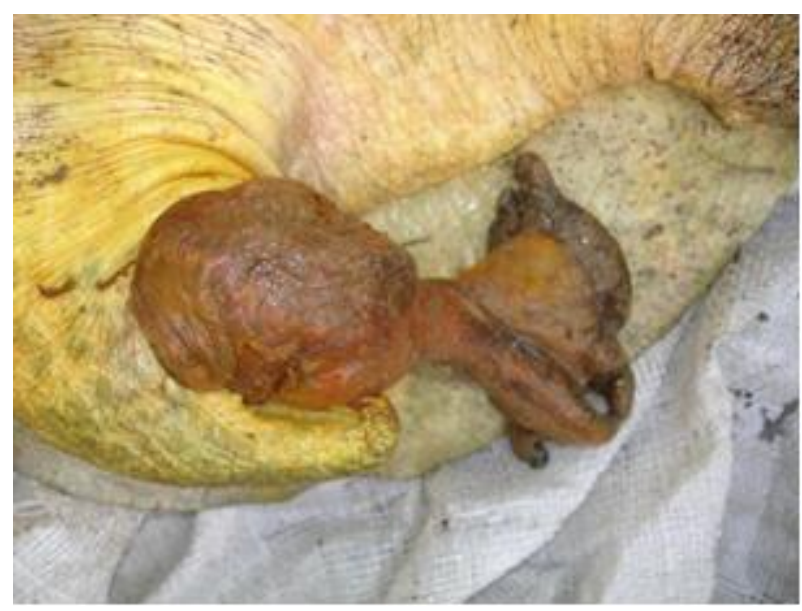

Figure 3. The prolapsed penis of Rafetus euphraticus with necrotic areas, hemorrhages and oedema

After the removing the larvae on penis, it was cleaned using with Isosol antiseptic dilution including $10 \%$ a/h Povidon iodine. After the antiseptic treatment, sugar powder was sprinkled on the prolapsed penis for the removal of oedema. Then sugar melted, and sugar powder was sprinkled again. This process was performed three times. Finally, it treated with boiled-chilled tea, after that oedema was decreased. The prolapsed penis was replaced into its normal anatomical position into the cloaca (Fig 4 A). The test-tube $(20 \mathrm{~cm})$ was used as auxiliary device. After the replacing the penis to prevent the rejection of the genital organ, it was sutured on the cloaca (Fig 4 B). The induction of epidural anesthesia was performed by intramuscular administration of Novalgin ( $2 \mathrm{mg} / \mathrm{kg}$ IM, Metamizol sodium) (Adeka, Samsun, Turkey) (4 different location on legs and tail) and jetocain (Lidokain $\mathrm{HCl} 20 \mathrm{mg} / \mathrm{ml}$, Epinefrin $\mathrm{HCl} 0.0125 \mathrm{mg} / \mathrm{ml}$ ) (Adeka, Samsun, Turkey) (local anesthesia around the cloaca and among tail vertebrae). Subsequently, to prevent the genital infection, induction of antibiotic was performed as $500 \mathrm{mg} / \mathrm{kg}$ iespor $(250 \mathrm{mg} / \mathrm{kg} \mathrm{IM}$, cefazolin sodium) (I.E. Ulagay, İstanbul, Turkey), once a day for 4 days after the operation. 


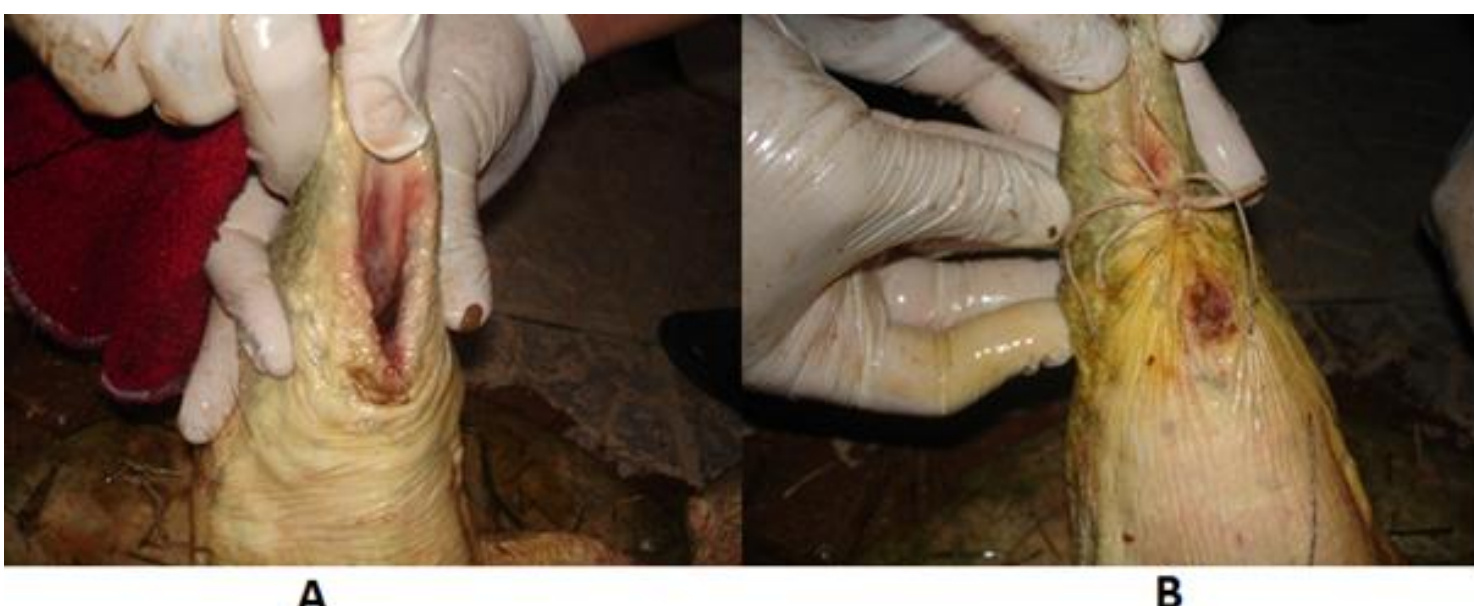

Figure 4. The prolapsed penis replacement seen normal anatomical position in the cloaca $(A)$ and sutured cloaca opening after replacement $(B)$

\section{DISCUSSION}

The presence of penis prolapse in chelonians is documented in veterinary textbooks (Barten 2006; Norton 1994), however, there is limited reports in veterinary literature (Nisbet et al., 2011; Sharma and Raghuvanshi, 2009). Penile prolapses may be results of infection, forced separation during copulation, inflammation, nutritional secondary hyperparathyroidism, neurologic or traumatic defects involving the retractor penis muscles or cloacal sphincter, and straining from intestinal parasites, impaction of the cloaca with gastrointestinal foreign bodies (Barten 2006; Norton 1994). Nisbet et al. (2011) and Korkmaz et al. (2014) reported that penis prolapse in a Red Eared Slider (Trachemys scripta slegans) was occurred after copulation. In our case, because of the Euphrates soft-shelled turtle was captured in the month of November, it is thought that the prolapse of the turtle could be result from reasons except the copulation. Contrary to this belief, mating season of Rafetus euphraticus can extend up to November.

\section{REFERENCES}

Barten, S.L. 2006. Penile Prolapse In: Mader DR (editor), Reptile Medicine and Surgery, 2nd ed., WB Saunders Company, Philadelphia, 862-864. doi: 10.1016/B0-72-169327-X/50068-7

Boyer, T.H. 1998. Emergency care of reptiles. Vet. Clin. North. Am. Exotic Anim. Prac. 1: 191-206.

IUCN, 2010. IUCN Red List of Threatened Species Version 2010.1. http://www.iucnredlist.org. Accessed 12 April 2010.

Innis, C., Boyer, T.H. 2002. Chelonian reproductive disorder. Vet Clin North Am Exotic Anim Pract. 5 (3): 555-578. doi: 10.1016/S1094-9194(02)00013-0

Korkmaz, M., Saritas, Z.K., Demirkan, İ. 2014. Surgical Treatment of Penile Prolapse in a Red Eared Slider (Trachemys scripta slegans). Research
It has been indicated that in such cases, where the penis tissue is still considered viable, the organ may be reduced. Before reducing the prolapsed tissue, it should be cleaned and any lacerations repaired. Moreover, the presence of oedema may be controlled with the application of cold compresses (Barten 2006; Norton 1994). We treated this lesion using with Povidon-lodine. Also, we applied to sugar powder to cure the oedema. Finally, we used the tea compress to take advantage of vasoconstrictor and antimicrobial effects on penile tissue. Raut et al. (2008) also reported that Estriol cream can be applied to reduce the possible hormone dependent congestion. However, the prolapsed penis should be amputated where the prolapsed phallus is necrotic (Barten, 2006; Boyer, 1998; Nisbet et al., 2011; Norton, 1994; Ojeh and Adetunji, 2008). In the present case, it was decided to use the prolactive treatment, due to the newly, small necrosis areas and lack of the hemorrhages. The treatment of penile prolapse case of Euphrates soft-shelled turtle gave the best result and no complication occurred. Following the antibiotic treatment, after the 1 week observation stage, the turtle was released to the nature at the Çatak location, Atatürk Dam Lake.

Journal for Veterinary Practitioners. 2 (1): 17 - 18. doi: $10.14737 /$ journal.rjvp/2014/2.1.17.18

Martinez-Jimenez, D., Hernandez-Divers, S.J. 2007. Emergency care of reptiles. Veterinary Clinics of North America: Exotic Animal Practice. 10 (2): 557-585. doi: 10.1016/j.cvex.2007.02.003

Nisbet, H.O., Yardımcı, C., Ozak, A., Sirin, Y.S. 2011. Penile Prolapse in A Red Eared Slider (Trachemys scripta elegans). Kafkas Üni. Vet. Fak. Derg. 17: 151-153.

Norton, T.M. 1994. Chelonian Emergency and Critical Care. Semin. Avian Exot. Pet. Med. 14: 106-130. doi: 10.1053/j.saep.2005.04.005 
Ojeh, C.K., Adetunji, A. 2008. Penile prolapse in a tortoise (Testudo gigantea). Afr. J. Ecol. 18 (2-3): 187-190.

Raut, B.M., Raghuwanshi, D.S., Upadhye, S.V., Gahlod, B.M., Khante, G.S. Borghare, A.P. 2008. Hormonal Management of rectal prolapse in a turtle. Vet. World. 1(8): 248.

Sharma, Y.K., Raghuvanshi, P.D.S. 2009. Surgical treatment of cloacal prolapse in a turtle. 112 Indian J. Vet. Surg. 30: 70
Taşkavak, E. 1995. Threats to survival of Euphrates soft-shelled turtle Rafetus euphraticus in southeastern Anatolia, Turkey. - in B. Devaux (1995) (ed.): Proceedings: International Congress of Chelonian Conservation, July 6 10, 1995. - SOPTOM, Gonfaron, France.

Taşkavak, E. 1998. Comparative morphology of the Euphrates soft-shelled turtle, Rafetus euphraticus (Daudin, 1802) (Reptilia, Testudines) in Southeastern Anatolia. - Amphibia-Reptilia. 19: 281-291. doi: $10.1163 / 156853898 \times 00188$ 